\title{
Nature's Osteopathy
}

By Lawrence Ostoforoff, Saskatchewan Museum of Natural Hisitory, Regina

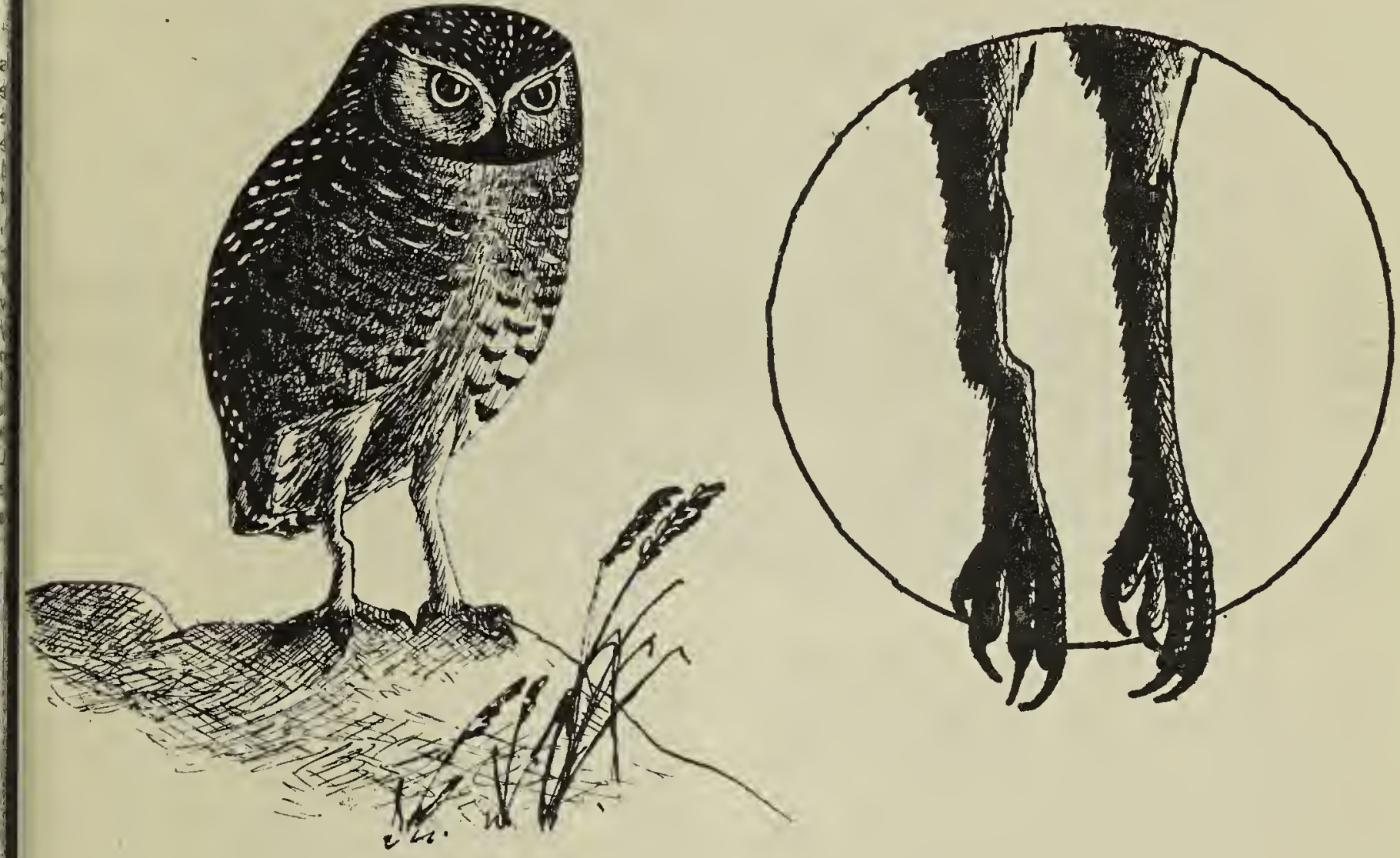

Burrowing Owl.

On Sepitember 28, 1958 a Burrowing Owl (Speotyto cunicularia) casulalty was picked up on highway No. 1 near Pilat Butte by W. Niesisen, staff member of the Saskatchewan Museum. Upon examining the specimen we found that its right leg had been ibroken but had healed into a nearly natural position (see sketch). Note that although the bone is not properly aligned, it healed in such a way that the toes still face forward.

Similar cases of natural healing have been observed by $F$. W. Lahrman of the Saskatchewan Museum. A Western Willet (Catoptrophorus semipalmatus) was observed to have one wing broken and dangling. Approximately one month later the bird was seen to fly perfectly.
Sketch by Lawrence Ostoforoft

In his field notes, Mr. Lahrman writes about a Canaida Goose (Branta canadensis) at the Wascana Sanctuary. Augusit 14, 1954, "Left tibia broken - was able to swim and move about on land by hopping on one foot." August 29, "Bearing some weight on left foot but limps while walking." September 13 (32 days after fracture), "Completely healeid and in natural position."

While doing taxidermy at the Museum I have noticed in several cases 'that birds' bones had been broken and amazingly healed in natural position while the bird undoubtedly was trying to use the limb. From this information one can conclude that if a bone is broken (tendons and veins still being intact) the pieces will often knit together quickly and in a natural position.

\section{SASKATCHEWAN NESTING RECORDS OF THE COOPER'S HAWK} Compiled by Dr. Stuart Houston, Yorkton.

The Cooper's Hawk was listed as "hypothetical" in Mitchell's "Birds of Saskatchewan" in 1924. The fifth edition of the A.O.U. Check-list in 1957 failed to include Saskatchewan in the breeding range of this species. Both of these publications overlcoked the records of Thomas Blakiston who found a nest with two eggs and collected the adult female near 
Carlton on May 21, 1858-one hundred years ago.

In actual fact, the Cooper's Hawk is a regular nester, at least in eastern Saskatchewan, where there are medium to large clumps of poplar. Indeed it is one of the hawks most commonly banded in Siaskatchewan! By contacting good observers in likely areas, I was able to compile the following list of representative Saskatchewan breeding records:

Armley (4 miles east of): May 24, 1935. Nest, 3 eggs, 28 ft. up in white poplar. - M. G. Street.

Armley (6 miles SSE of): June 28, 1936. 3 young out of nest, thought to have come from nest over $20 \mathrm{ft}$. up in white poplar. - M. G. Street.

Sheho (31/2 mi. NW of): July 26, 1948. Nesit, 4 young, 20 ft. up in white poplar. 3 banded; one flew. - M. G. Street.

Sheho (33/4 mi. NW of ): July $26,1948$. Nest $16 \mathrm{ft}$. up in white poplar. 1 young a:ble to fly; amount of down suggested 2 or 3 nestmates. - M. G. Street.

Spirit Lake (NW $1 / 4$ of sec. 11, twp. 29, range $5 \mathrm{w}$. 2nd mer). May $1 \dot{\text {, }}$, 1951: nest $20 \mathrm{ft}$. up in white poplar. 4 young on July 4.- - W. Anaka.

Spirit Lake (SW 13-29-5w2). May 12, 1955: nest $20 \mathrm{ft}$. up in balsam pcplar. 4 downy young banded on July 6. - W. Anaka.

Spirit Lake (NW 11-29-5w2). May 30, 1956: nest 20 f.t. up in balsam poplar. 4 young banded on July 15 - W. Anaka.

Spirit Lake (SW 13-29-5w2). May 26, 1957: nest $25 \mathrm{ft}$. up in balsam poplar. 1 young banded on July 25 ; one or two flew away. - W Anaka.

Spirit Lake (SW 13-29-5w2). June 1, 1958: nest, 5 eggs, 22 ft. up in balsam poplar. 3 downy young on June $30 ; 2$ full-grown young cut of nest banded July 23. - W. Anaka.

Yorkton (Leech Lake, 10 miles south ): Nes'. 3 eggs, found May 28, 1945 by J. H. Wilson Visited June 8,1945 by W. H. Carrick.

Yorkton ("muskeg" at west city limits): Junc 10, 1947. Nest, 3 eggs, $22 \mathrm{ft}$. up in balsam poplar. 2 young banded July 11. - S. Houston.

Yorkton (York Lake. 4 miles SW): May 31, 1953. Nest $20 \mathrm{ft}$. up in balsam poplar. 2 young banded July 12. - S. Houston

Saltcuats ( $1 / \%$ mile NE). 1956. Nest, 3 eggs, in white poplar.-Bill Horseman.
Bredenbury ( 9 miles SW). 1956. Nest 4 eggs, in white poplar. - Bil Horseman.

Saltcoats ( 1 mile N.): May 23, 1958 Nest, 3 eggs, 20 ft. up in whit poplar, 1 of the 2 young banded on July 19. - Bill Horseman.

Saltcoats ( $3 / 4$ mile E): Miay 28, 1958 Nest, 1 egg, 20 f.t. up in white poplar. Egg then disappeared, anc she renested with 3 eggs on July 18. Only one young was raised; i was banded Aug. 12 and was stil in nest on August 31.-Bill Horseman.

Saltcoats ( 3 miles NW): June 17 1958: nest, 2 young, $25 \mathrm{ft}$. up ir white poplar. Banded June 22 (by Houston). - Bill Horseman.

Round Lake, Qu'Appelle Valley (1/2 mile wesit): May 27, 1945. Nest, eggs, 15 or $20 \mathrm{ft}$. up in poplar a northern edge of marsh. - E. M Callin.

Qu'Appelle (Pasqua) Lake (few miles west): May 18, 1954. Nest ready for eggs, $20 \mathrm{ft}$. up in poplar near bottom of north slope of valley. One adult present and quite agitarted. - E. M. Callin.

Fort Qu'Appelle (Echo Creek, wes town limits): June 12, 1955. Nest 1 egg and 1 newly-haitohed young $20 \mathrm{ft}$. up in balsam poplar (climbec by Houston). - E. M. Callin.

Qu'Appelle Lake, Pasqua Indian Re serve, N.W. of Muscow: 1925 . young, 2 of which were bandec July 16, 1925. - R. H. Carter.

B o g g y Creek, Lumsden (11-19. 21w2): Nest, 4 or 5 young, abou 1944. - Doug Gilroy.

B o g g y Creek, Lumsden (12-19. 21w2): Nest, 2 downy white young $20 \mathrm{ft}$. up in maple, July 5, 1955 Next day young had disappeared - Doug Gilroy.

B o g g y Creek, Lumsden (26-19. 21w2): Nest 4 or 5 young, June 30 1956: 3 young out of nest bander by Houston on July 15. - Dous Gilroy.

I have fcund the Cooper's Hawk tc be a rather secretive and wary birc -it is not likely to be fcund during "roadside birding" from an auto mobile. Indeed, I have not identifiec it during the breeding season excep at its nest. Like the Long-eared Owl if you see the bird at all in June o July, you will almost always find it nest. The Cooper's Hawk is undoubt edly much commoner in Saskatch ewan than has bee $n$ generall: realized. 